\title{
EGY ROBOTPROGRAMOZÁS SZAKKÖR MUNKATERVÉNEK BEMUTATÁSA
}

\section{Szerzők:}

Csernai Zoltán

Eszterházy Károly Egyetem

Szerző e-mail címe:

csernai.zoltan@uni-eszterhazy.hu

\section{Lektorok:}

Racsko Réka (PhD)

Eszterházy Károly Egyetem

Kis-Tóth Lajos (PhD)

...és további két anonim lektor

\section{Absztrakt}

A tanulmányban a LEGO® MINDSTORMS Education EV3 robotprogramozás szakkör munkatervének ismertetésére kerül sor. Az Eszterházy Károly Egyetem Gyakorló Általános, Közép-, Alapfokú Mûvészeti Iskola és Pedagógiai Intézetben a felső tagozatos tanulók 90 perces foglalkozások keretein belül megismerték a LEGOR módszertanát és a Computational Thinking (CT) készségkategóriáit a különböző miniprojektek megoldása során.

Kulcsszavak: LEGO, EV3, robotprogramozás, Computational Thinking

Diszciplina: pedagógia, informatika

\section{Abstract \\ PRESENTATION OF A ROBOT PROGRAMMING WORK PLAN}

The study describes the work plan of the LEGO® MINDSTORMS Education EV3 robot programming. In the Primary, Secondary, Primary School of Art and Pedagogy of the Károly Eszterházy University, the upper secondary students got acquainted with the LEGOR methodology and the skills categories of Computational Thinking (CT) in solving various miniprojects within the framework of 90-minute sessions.

Keywords: LEGO, EV3, robot programming, Computational Thinking

Disciplines: pedagogy, informatics

Csernai Zoltán (2020): Egy robotprogramozás szakkör munkatervének bemutatása. Mesterséges intelligencia - interdisžciplináris folyóirat, II. évf. 2020/2. szám. 45-52. doi: 10.35406/MI.2020.2.45 


\section{A robotika szerepe}

\section{a Nemzeti Alaptantervben}

A 2020-as Nemzeti Alaptantervben a robotika fogalma a „II.3.8.1. Digitális kultúra” tantárgy fő témakörei között a 3-4. évfolyamon (lásd. a robotika és a kódolás alapjai) és az 5-8. évfolyamon (lásd. robotika) található meg. A robotika alapjainak megismerése azért fontos, mert segítségével a tanuló egy valódi vagy szimulált programoz-ható eszköz mozgását értékelni tudja, hiba esetén pedig módosítja a kódsorozatot a kívánt eredmény elérése céljából. A feladatok megoldása során tehát az adott feltételeknek megfelelő kódsorozatok tervezése, végrehajtása és módosítása történik. Kiemelten fontos szerepet kap a tapasztalatok megfogalmazása és megvitatása a diáktársakkal.

\section{A LEGO® módszertana}

\section{és a Computational Thinking (CT)}

A LEGO® cég a projektek megvalósítását három fázisra tagolja:

- A felfedezés fázisa: ebben a fázisban a tanulók megismerkednek a feladattal, meghatározzák a kívánt kutatási irányt, valamint számba veszik a lehetséges megoldásokat. A felfedezés fázisának elemei a megismerés és a vélemény-csere.

- Az alkotás fázisa: egy robotkons-trukció megépítése, beprogramozása és újragondolása történik a projektek megvalósításának ezen fázisában.

- A megosztás fázisa: a LEGO® robo-tok segítségével az eredmények ismer-tetése, illetve a kutatási dokumentum bemutatása történik ebben a fázisban.

A Computational Thinking (CT) négy készségkategória kombinációja:

- Elemi részekre bontás: a bonyolult probléma könnyebben kezelhető, kisebb részekre való bontása.

- Mintafelismerés: a minták és trendek felismerése, beazonosítása, amely elősegítik a problémamegoldást.

- Az absztrakció megértése: a felesleges információk eltávolítása abból a célból, hogy az adott problémára összpontosítsunk.

- Algoritmusok létrehozása és használata: az algoritmus elemi lépések meghatározott sorrendú, véges sorozata, amely lehetővé teszi a probléma megoldását.

A felső tagozatos diákok a LEGO® módszertanát és a Computational Thinking (CT) készségkategóriát együttesen alkalmazták a gyakorlati jellegû miniprojektek megoldása során.

\section{A robotprogramozás szakkör}

A LEGO® Education oktatási eszközei úgy lettek kifejlesztve, hogy támogassa a tanulók kreativitását, együttműködési kész-ségeit és problémamegoldó képességeit. A cégnek az a küldetése, hogy a leglátványosabb és legkreatívabb STEM (Science, Techology, Engineering, Mathematics) tanulási eszközök használatával elôsegítse az aktívabb elköteleződést és a sikeres eredményeket biztosítson a gyakorlati tanulás révén. 
A LEGO® cég harmadik generációs robotja 2013-ban került kereskedelmi forgalomba. Az oktatás számára készült változat LEGO® Mindstorms Education EV3 néven került piaci értékesítésre. A robotkészlet elektromos alkatrészei közé tartozik: $2 \mathrm{db}$ nagy szervo motor, $1 \mathrm{db}$ közepes szervo motor, 1 db ultrahangos távolságérzékelő, 1 $\mathrm{db}$ szín szenzor, $1 \mathrm{db}$ giro szenzor, $2 \mathrm{db}$ ütközés érzékelő és $1 \mathrm{db}$ központi vezérlő egység (tégla). A tanulók a számítógépen vagy tableten elkészített programot USB kábelen vagy bluetooth-on keresztül töltik fel a robotra. A szenzorok által érzékelt adatok alapján a robot döntéseket hoz a szükséges tevékenységről, amelyet a motorjai segítségével végrehajt.

A robotprogramozás szakkör célja az volt, hogy a tanulók megismerjék a mobil-robottechnikai alapfogalmakat, a robotkészlet szenzorainak jellemzőit, karakterisztikáját és az alkalmazásuk lehetôségeit. A foglalkozások során a diákok elsajátították az EV3-G programnyelvet, valamint gyakorlatot szereztek a mobilrobotok összeállításában, tesztelésében és futtatásában.

Az Eszterházy Károly Egyetem Gyakorló Általános, Közép-, Alapfokú Mûvészeti Iskola és Pedagógiai Intézetben hetente egy alkalommal, 90 perces foglalkozások keretein belül került megtartásra a robotprogramozás szakkör az érdeklődő felső tagozatos tanulók számára.

Az EFOP-3.2.15 „A Köznevelés keretrendszeréhez kapcsolódó mérési-értékelési és digitális fejlesztések, innovatív oktatásszervezési eljárások kialakítása, megújítása" című pályázat keretein belül Kiss Róbert, kecskeméti középiskolai tanár közremúködésével kidolgozásra került a robotprogramozás szakkör 15 hetes munkaterve, amely a továbbiak során foglalkozásokra bontva röviden bemutatásra kerül.

Az 1. foglalkozás témái a robot felépítése, hardver elemei és az alaprobot építése. A foglalkozás elején, kb. 10 percben a robot hardver elemi kerülnek bemutatásra, vagyis a tégla, a szenzorok, az input/output portok, a be- és kikapcsolás folyamata, a robot múködési elve. Rövid, lényegre törő bemutatás legyen, amelyet tanári magyarázat kísérjen. Ezt követően, kb. 80 percben a tanulók a LEGO® hivatalos oldalán található építési útmutatók alapján felépítik a Robot Educator alaprobotot. A robot építési folyamata önálló tanulói munka, azonban szükség esetén biztosítson a tanár segítséget.

A 2. foglalkozáson a szoftverkörnyezettel, a motorok használatával ismerkednek meg a tanulók, valamint elsajátítják a derékszögű fordulást és a különböző mozgásvonalakat. A foglalkozás első részében, kb. 15 percben a robotszoftver bemutatására kerül sor. A tanár röviden, lényegre törően ismerteti a blokkok csoportjait, a programszál építését, a blokkok működési módjait, paramétereit, a programok feltöltési folyamatát a robotra és a programok indításának lehetőségeit. Ezután, kb. 25 percben a motorok használatára kerül sor. Bemutatásra kerül a Move Steering és Move Tank blokkok használata, az előre és hátra mozgás, a mozgás időtartamának vezérlése a Seconds, Degrees, Rotations segítségével. A diákoknak időt kell hagyni arra, hogy kísérletezzenek a 
robot mozgatásával. Min-denképpen érdemes kipróbálni az előre és vissza történő mozgást, valamint az íven és helyben fordulást. Ezt követően egy olyan program készítése a feladat, amely során a robot derékszögben fordul. A derékszögű fordulást célszerū kb. 15 percben megva-lósítani, hiszen a tanári magyarázat után lehetőséget kell adni a gyakorlatban történő tesztelésre. A foglalkozás utolsó $\mathrm{kb}$. 35 percében a feladatspecifikációban megadott, különböző pályákat bejáró robotprogramok önálló elkészítése a feladat.

A 3. foglalkozáson a szenzorok alap használata, a W ait blokk működése a téma. A foglalkozás első részében, kb. 30 percben elkészítésre kerül a szenzorvezérlet mozgás programja, amely abból áll, hogy a robot haladjon előre és egy akadálytól 15 centiméterre álljon meg. Az akadálynál forduljon kb. 90 fokot valamelyik irányba és haladjon fehér felületen egy piros vonalig, ahol álljon meg. Ezután tolasson hátra mindaddig, amíg az ütközésérzékelőjét nyomás nem éri, ekkor álljon meg. Következő feladatként érdemes elkészíteni az asztal szélén megálló robot programját is. A foglalkozás maradék idejében, kb. 60 percben a feladatspecifikációban megadott, különböző pályákat bejáró robotprogramok önálló elkészítése a feladat.

A 4. foglalkozás a „Királylány szabadítás” miniprojekt. A robotnak az a feladata, hogy a „Királyi vár”-tól indulva eljusson a királylányig. Fontos szabály az, hogy a robot a mozgás közben nem érintheti meg a hegyeket szimbolizáló dobozokat és nem mehet keresztül a tavakon. Ha hozzáér a dobozokhoz vagy teljes terjedelmében áthalad a tavak bármelyikén, akkor újra kell kezdenie a mozgását a „Királyi vár”-tól. A tanári feladatkitűzés után a tanulók önálló csoportmunkában oldják meg a feladatot.

Az 5. foglalkozás a vezérlési szerkezetek, ciklusok és elágazások. Az első feladat a négyzet alakú pályán mozgó robot programjának elkészítése. Célszerű ezt a feladatot továbbfejleszteni a párhuzamos szálú programozás segítségével úgy, hogy a négyzet alakú pályán mozgó robotot állítsuk meg az ütközésérzékelő szenzor benyomásával. A ciklusok és elágazások bemutatására kb. 40 percet fordítsunk, majd ezt követően a diákok önálló tanulói munkával oldják meg a feladatspecifikációkban megfogalmazott feladatokat.

A 6. foglalkozás témája az útvonalkövetés. Az ,útelágazás” feladatban a robotnak a zöld X-szel jelölt pozícióból a nyíl irányába indulva végig kell járnia a három akadályt piros, sárga, kék sorrendben. A robot a mozgása során a pályán lévő vonalakat kell, hogy kövesse. Erre a feladatra kb. 50 percet számoltunk. A foglalkozás másik feladata a „kockakeresés”, amelyben a robotnak a zöld X-szel jelölt helyről a nyíl irányába indulva, el kell mozdítania a kockákat a helyükrôl. A robot csak a rácsvonalak mentén mozoghat. A kockákat bármelyik rácspontba letehetjük. A feladat megoldására kb. 40 perc áll rendelkezésre önálló tanulói munkával.

A 7. foglalkozáson a többszálú elágazás készítése és a „Színválogató robot” miniprojekt megoldása a feladat. A többszálú 
elágazások létrehozásának technikáját a színszenzor esetén érdemes megmutatni a foglalkozás kb. 10 percében. A „Színválogató robot" miniprojekt arról szól, hogy írjunk egy olyan programot, amelynek végrehajtása során a robot egyenesen előre halad, majd az előtte levő piros, kék, zöld színű LEGO® elemek közül kiválogatja a piros színúeket. Az építést nem érdemes megmutatni, hiszen az is feladat, hogy a tanulók találjanak ki olyan eszközt (kart), amellyel megoldható a feladat. Segítségként a Medium Motorra érde-mes felhívni a figyelmet. A feladat meg-oldásának optimális ideje $\mathrm{kb} .80$ perc.

A 8. foglalkozás témája a „Hangszer” miniprojekt. Minden csapatnak közösen kell egy általuk választott dallamot lejátszani a robotok segítségével. A választott dallam kottáának megfelelő hangokat kell a robot gombjaira programozni. A feladatismertetés után célszerű egy videofelvételt lejátszani a végeredményről. A projekt elkezdése előtt a tégla nyomógombjainak programozását tanári magyarázattal érdemes bemutatni. A feladat megoldása elsősorban a közös munkát, a csoportkohéziót erősíti.

A 9. foglalkozás a paraméterátadás, illetve a paraméterek kiíratása a képernyőre. A foglalkozás során egyszerủ interaktív programok megoldására kerül sor. Első feladatként egy olyan programot kell készí-teniük a tanulóknak, amelyet végrehajtva a robot fehér alapú pályán elhelyezett fekete színű sávok fölött halad. A robot moz-gásának sebességét a fényérzékelőjével mért érték határozza meg, vagyis, ha a robot fehér színú felület felett halad, akkor gyorsabban mozog, míg fekete színű felület felett lassabban. Második feladatként a robot az ultrahangos távolságérzékelője által centi-méterben mért értékkel arányos sebességgel halad egy akadály felé folyamatosan lassulva. Ha az akadályt 5 centiméterre megközelítette, akkor álljon meg. Harmadik feladatként a robot egy tetszőleges pontról elindulva tegyen meg egy távolságot, például egy színes vonalig, majd elérve a vonalat vissza kell tolatnia a kiindulási pozícióba. Mivel nem tudjuk a színes vonaltól való távolság-mértékegységet mérni, ezért azt mérjük, hogy mennyi idő alatt ér el a robot a színes vonalig. Utolsó feladatként, a paraméterek képernyőn történő megjelenítése során olyan egyszerū programot készíthetünk, hogy a robot folyamatosan írja ki a képernyőre az ultrahangos távolságérzékelője által mért értéket.

A 10. foglalkozáson az EV3 képernyőjének felépítése, a képernyőkezelés utasításblokkjai, a Text, Shapes, Image, Reset Screen múködési módok, az adatok kiíratása és a rajzok megjelenítése a képernyőn kerül bemutatásra. Az első feladat az, hogy a robot a fényszenzora által mért értéket folyamatosan írja ki a képernyőre. Érdemes újra felhasználni a párhuzamos szálú programozás során tanultakat egy olyan program elkészítéséhez, hogy a robot folyamatosan jelenítse meg a képernyőjén a robotprogramozás szakkörön készült képet mindaddig, amíg az ütközésérzékelőjét nyomás nem éri. $\mathrm{Az}$ ütközésérzékelő megnyomására játssza le a „Stop” hangot.

A 11. foglalkozás témája a koordinátageometriai rajzok képernyőn történő megje- 
lenítése. Első feladatként az EV3 képernyőjén jelenítsünk meg három darab négyzetet úgy, hogy befelé haladva egymáshoz képest 45 fokkal legyenek elforgatva, és a belső négyzetek csúcsai a külső négyzetek oldalfelező pontjaira illeszkedjenek. A második feladat az, hogy rajzoljunk egy célkeresztet a robot képernyőjére a megadott koordináta pontok segítségével. Harmadik feladatként egy borítékot jelenítsünk meg a képernyőn. Negyedik feladatként az előzőleg elkészített boríték zárt és nyitott változatát váltogassuk a képernyőn az ütközésérzékelő megnyomásával. Az ötödik feladat az, hogy egy 10 pixel sugarú kört mozgassunk a képernyőn balról jobbra.

A 12. foglalkozáson a tanulók a matematikai és logikai műveletek, a véletlen számok és a matematikai műveletek használatát, illetve a logikai kapcsolatokat sajátítják el az összetett feltételekben. Első feladatként egy olyan programot készítünk, amely az 1-től 90-ig terjedő tartományból véletlenszerūen kiválaszt 5 darab számot és egymás alatti sorokban megjeleníti a képernyőn. Második feladatként a képernyőre rajzolunk véletlenszerú helyekre 10 darab fekete színú 3 pixel sugarú kört, mintha egy céltáblára érkező lövésnyomok lennének. Harmadik feladatként egy véltelen mozgással működő robotot készítünk. A motor két paraméterét, vagyis a kanyarodást és a mozgásirányt vezéreljük véletlenszerūen. Negyedik feladatként a logikai kapcsolatokat felhasználva a robotnak egyenesen előre kell mozognia és megállnia, ha valamilyen akadály elé kerül, de ez az akadály lehet egy piros színú vonal vagy egy doboz is. Tehát két különböző szenzort kell figyelnie és ha valamelyik jelez, akkor arra megállással reagál. Ötödik feladatként egy olyan programot írunk, amelyet végrehajtva a robot a képernyőre kiírja a következő sorozatelemeket: 2; 13; 24; 35; 46; 57; 68; 79; $90 ; 101$. A program a sorozat tagjait számítással határozza meg. A sorozat elemei az ütközésérzékelő szenzor megnyomásáig láthatók a képernyőn.

A 13. foglalkozás témája a bluetooth kommunikáció és a távirányítós kisautó feladat. Az egyirányú kommunikációra épülő programozás segítségével az egyszerű üzenetküldést tesztelhetjük le. Ehhez két robot között ki kell építenünk bluetooth kapcsolatot, majd az a feladat, hogy a mester robot küldjön egy üzenetet a szolga robotnak. Az üzenet tartalma például lehet a „Hello” karaktersorozat. A feladat megoldása során a két robotra különböző programot kell írnunk: a mesterre egy üzenetküldő progra-mot, a szolgára pedig egy üzenet fogadó programot. A távirányítós kisautó feladatban a két robot közül az egyik lesz a jármú a másik pedig a távirányító. Azt kell megolda-nunk, hogy a jármű robot tudjon kanyarodni mindkét irányban, előre haladni és tolatni, valamint változtatni a sebességét. Harmadik feladatként egy színfelismerő programot készítünk. A szolga robot a színérzékelő szenzor által mért értéket folyamatosan átküldi a mesternek. A mester robot pedig szövegesen a képernyőjére írja ki azt, hogy aktuálisan milyen színt lát a szolga.

A 14. foglalkozás a „Fenyőfaszállítás” miniprojekt. Az a feladat, hogy írjunk egy olyan 
programot, amelynek végrehajtása során a robot megkeres egy fenyőfát. A robot előtt három fekete színű útvonal látható, amely mindegyikének végén egy-egy akadály található. Valamelyik akadály előtt egy fenyőfa van elhelyezve. A fenyőfa bármelyik akadály előtt lehet. A robot feladata tehát az, hogy elinduljon a három fekete színú útvonalra merőlegesen és hozza el a fenyőfát az akadály elől. Célszerű a feladat megoldását szétbontani a következő tevékenységekre: az adatok bejuttatása a robot programjába, a robot mozgása a fenyőfához, a fenyőfa mozgatása. A tanári magyarázat során térjünk ki a nyomógombok segítségével történő számolásra és a változók használatára, de csak olyan mélységig beszéljünk róla, ami a feladat megoldáshoz szükséges.

A 15. foglalkozás a tanulók nagy kedvence, a „Robotszumó” miniprojekt. A szumó robotok a küzdőtéren mozogva megkeresik az ellenfelet, majd letolják a küzdőtérről vagy mozgásképtelenné teszik őket. A robot akkor tekinthető a küzdőtérről kiesettnek, ha valamely része a talajt érinti. Minden robot 100 százalékban eredeti LEGO® alkatrészekből kell, hogy álljon és a súly nem lehet több 2 fontnál ( 2 font $=0,909 \mathrm{~kg}$ ). A robotnak el kell férnie 1x1x1 lábnyi (1 láb = 30,48 centiméter) kockában. A robot kötelező eleme a LEGO® MINDSTORMS tégla. A foglalkozás során adjunk lehetőséget a diákoknak a saját szumó robotjuk megépítésére, majd közösen készítsünk hozzá egy minta programot.

\section{Összefoglalás}

A robotprogramozás szakkörön a feladatok megoldása során a felső tagozatos diákok szívesen használták a LEGO ${ }^{\circledR}$ Mindstorms Education EV3 robotot. A játékos, gyakorlati, motiváló feladatokon keresztül a gyerekek sikeresen alkalmazták a LEGO® módszertanát és a Computational Thinking (CT) készségkategóriát. A miniprojektek megoldása során ezen kívül a tanulók megismerték más diáktársuk ötleteit, megoldásait, ezáltal tanultak is egymástól.

Jövőbeli céljaink közé tartozik a robotprogramozás szakkör következő féléves munkatervének kidolgozása és gyakorlatban történő tesztelése az Eszterházy Károly Egyetem Gyakorló Általános, Közép-, Alapfokú Művészeti Iskola és Pedagógiai Intézetben a koronavírus-járvány után, valamint a hazai és nemzetközi robot versenyeken való szereplés.

A LEGO® Education oktatási eszközei segítségével a tanulók elsajátítják a dinamikus tanulás képességét. A robotprogramozás szakkörön a gyakorlati jellegű miniprojektek olyan kihívás elé állították a tanulókat, amely arra késztette őket, hogy a feladatok megoldása során használják a képzeletüket, javítsák a probléma-megoldó készségüket és a másokkal való együttmúködésüket. A foglalkozások során a diákok olyan létfontosságú készségekre tehettek szert, amely a jövőbeli sikerük záloga lehet.

\section{Köszönetnyilvánítás}

Szeretnék köszönetet mondani Lengyelné dr. Molnár Tündének, Légrádiné Kőházi 
Tímeának, Szűcsné Hütter Eszternek és Kiss Róbertnek, hogy támogatásukkal megvalósulhatott az Eszterházy Károly Egyetem Gyakorló Általános, Közép-, Alapfokú Mûvészeti Iskola és Pedagógiai Intézetben a robotprogramozás szakkör.

Az EFOP-3.2.15 „A Köznevelés keretrendszeréhez kapcsolódó mérési-értékelési és digitális fejlesztések, innovatív oktatásszervezési eljárások kialakítása, megújítása” c. pályázat keretein belül került kidolgozásra a robotprogramozás szakkör munkaterve.

\section{Irodalom}

Csernai, Z. (2020). A Computational Thinking (informatikai gondolkodás) elemeinek fejlesztése az általános iskolában: egy robotprogramozás szakekör tapasztalatai. Agria Média 2020 és ICI-16 Információ- és Oktatástechnológiai konferencia. Eszterházy Károly Egyetem. Eger, 2020. október 7-9. (megjelenés alatt)

Csernai, Z. (2020). Az informatikai gondolkodással kapcsolatos vélekedések az. Eszterházy Károly Egyetem osztatlan informatikatanár szakos hallgatói körében. Networkshop 2020. Pécsi Tudományegyetem. Pécs, 2020. szeptember 2-4., (megjelenés alatt)

Kiss, R. (2014). A MINDSTORMS EV3 robotok programozásának alapjai. H-Didakt
Kft. Letöltés: 2020.12.20. Web: http://hdidakt.hu/wpcontent/uploads/2016/01/dw_74.pdf

Kiss, R. (2016). Robotika feladatgyüjtemény. HDidakt Kft. Letöltés: 2020.12.20. Web: http://hdidakt.hu/wpcontent/uploads/2016/02/Robot_felada gyujtemeny_EV3_NXT.pdf

Kiss, R. (2019). Robotprogramozás alkalmazása az oktatásban. Eszterházy Károly Egyetem, Eger. Letöltés: 2020.12.20. Web: https://tanfolyam.uni-eszterhazy.hu/

Net1: LEGO® Education SPIKE ${ }^{\mathrm{TM}}$ Prime. Letöltés: 2020.12.20. Web: https:/ /hdidakt.hu/wpcontent/uploads/2020/03/LE_SPIKE_P rime_booklet_A4_hu_low.pdf

Net2: LEGO ${ }^{\circledR}$ MINDSTORMS ${ }^{\circledR}$ Education EV3. Letöltés: 2020.12.20. Web: https://hdidakt.hu/le-

mindstorms/mindstorms-ev3/

Net3: Magyar Közlöny 2020. évi 17. sqám. Letöltés: 2020.12.20. Web: https://magyarkozlony.hu/dokumentum ok/3288b6548a740b9c8daf918a399a0bed 1985db0f/megtekintes

Net4: Nemzetköri és hazai robot versenyek. Letöltés: 2020.12.20. Web: https://hdidakt.hu/robot-versenyek/ 